\title{
The Diagnostic Significance of Serum Alcohol Dehydrogenase Isoenzymes and Aldehyde Dehydrogenase Activity in Prostate Cancer Patients
}

\author{
KAROLINA ORYWAL ${ }^{1}$, WOJCIECH JELSKI ${ }^{1}$, TADEUSZ WEREL ${ }^{2}$ and MACIEJ SZMITKOWSKI ${ }^{1}$ \\ Department of ${ }^{1}$ Biochemical Diagnostics and ${ }^{2}$ Department of Urology, \\ Medical University of Bialystok, Bialystok, Poland
}

\begin{abstract}
Background/Aim: The aim of this study was to investigate a potential role of alcohol dehydrogenase (ADH) and aldehyde dehydrogenase (ALDH) as tumor markers for prostate cancer (PCa). Materials and Methods: Serum samples were obtained from 52 patients with $P C a, 34$ patients with benign prostatic hyperplasia $(\mathrm{BPH})$ and 60 healthy subjects. Class III and IV of ADH and total ADH activity were measured by the photometric method. For measurement of class I and II ADH and ALDH activity, the fluorometric method was employed. Results: Significantly higher total activity of $A D H, A D H$ III and $A D H I V$ were found in the sera of both, PCa and BPH patients compared with healthy individuals. The diagnostic sensitivity for $A D H$ III activity was $94.2 \%$, specificity 100\%, PPV (positive predictive value) and NPV (negative predictive value) were $100 \%$ and $95.2 \%$ respectively. Area under receiver-operating characteristics (ROC) curve for ADH III activity was 0.993. Conclusion: The results suggest a potential role of $A D H$ III activity as a parameter included in the panel of markers for PCa.
\end{abstract}

Prostate cancer (PCa) is one of the commonly diagnosed malignancies in men worldwide and the second leading cause of death from cancer disease (1). Patients in early stage of $\mathrm{PCa}$ can be cured with radical prostatectomy or radiotherapy, with or without androgen ablation. Metastatic $\mathrm{PCa}$, with secondary lesions found mostly in the skeleton, has very high mortality and morbidity (2). The standard method for diagnosis of PCa involves prostate biopsy, but due to its diagnostic limitations and invasive nature, it has

Correspondence to: Karolina Orywal, Department of Biochemical Diagnostics, Medical University of Bialystok, Waszyngtona 15 A, PL 15-276 Bialystok, Poland. Tel: +48 857450987, Fax: +48 857450585,e-mail: orywalk@umb.edu.pl

Key Words: Alcohol dehydrogenase isoenzymes, aldehyde dehydrogenase, prostate cancer, cancer markers, diagnostic utility. only partial utility. Prostate specific antigen (PSA) is the most commonly used serum marker for the detection of prostate cancer. Because of its lack of specificity in $\mathrm{PCa}$ screening, there is a clinical need for new prostate cancer markers to decrease unnecessary prostate biopsies (3).

Epidemiological studies have demonstrated a correlation between ethanol consumption and the occurrence of cancers in many organs. Worldwide, about $3,6 \%$ of all cancers were attributable to alcohol drinking and the International Agency for Research on Cancer (IARC) classified alcohol consumption as group 1 of human carcinogens (4). A relationship has been established between alcohol and cancers of oral cavity, pharynx, larynx, esophagus, stomach, liver, pancreas, colon, rectum and breast. Significantly increased risk of prostate cancer caused by ethanol consumption have been also noticed in few cohort studies $(5,6,7)$. The exact mechanism by which alcohol consumption enhances carcinogenesis is still unexplained. Alcohol is oxidized primarily by alcohol dehydrogenase $(\mathrm{ADH})$ to acetaldehyde, a substance capable of initiating carcinogenesis by forming adducts with proteins and DNA and causing mutations. Next, acetaldehyde is metabolized by aldehyde dehydrogenase (ALDH) to acetate.

In tissues of many cancers, we can observe disproportion between alcohol dehydrogenase and aldehyde dehydrogenase activities in comparison to healthy cells. These disturbances could be the cause of elevated production of carcinogenic acetaldehyde and also disorders in the metabolism of many biologically important substances e.g. retinoic acid (8). Many studies have shown that cancer cells of many organs may release $\mathrm{ADH}$ isoenzymes to the blood raising the possibility of using the measurement of $\mathrm{ADH}$ activity in cancer diagnostics.

In the current study, we determined the differences in the activity of alcohol dehydrogenase isoenzymes and aldehyde dehydrogenase in the sera of patients with PCa. Moreover, we defined the diagnostic utility (sensitivity, specificity, predictive value for positive and negative results, and receiver-operating characteristics (ROC) curve) of $\mathrm{ADH}$ isoenzymes in prostate cancer. 


\section{Materials and Methods}

Materials. Blood samples were obtained before cancer resection from 52 patients with prostate cancer (mean age 65 years, range $=58-86$ years), hospitalized in Clinical University Hospital in Białystok, Poland. None of the patients had received chemotherapy, radiotherapy or immunotherapy before sample collection. We determined two control groups from which serum samples were taken: 34 patients (mean age 55 years, range $=52-69$ years old) with benign prostatic hyperplasia (BPH) and 60 healthy men (mean age 58 years, range $=51-67$ years old). All of patients (both studied and control groups) had a history of occasional alcohol consumption.

The research protocol was approved by the Medical University of Białystok's Human Care Committee located in Bialystok, Poland (Approval No R-I-002/185/2016). All patients gave their informed consent for the examination.

\section{Methods \\ Determination of total ADH activity. Total ADH activity was estimated by the photometric method using p-nitrosodimethylaniline (NDMA) as a substrate (9). The reaction mixture $(2 \mathrm{ml})$ contained serum $(0.1 \mathrm{ml}), 1.8 \mathrm{ml}$ of a $26 \mu \mathrm{M}$ solution of substrate in $0.1 \mathrm{M}$ of sodium phosphate buffer, $\mathrm{pH} 8.5$ and $0.1 \mathrm{ml}$ of mixture containing $0.25 \mathrm{M}$ n-butanol and $5 \mathrm{mM}$ NAD. The reduction of NDMA was monitored at $440 \mathrm{~nm}$ on a Shimadzu UV/VIS 1202 spectrophotometer (Shimadzu Europa GmbH, Duisburg, Germany).}

Determination of total ALDH activity. Aldehyde dehydrogenase activity was measured using the fluorogenic method based on the oxidation of 6-methoxy-2-naphtaldehyde to fluorescent 6-methoxy2 -naphtoate (10). The reaction mixture contained $60 \mu \mathrm{l}$ of serum, 60 $\mu \mathrm{l}$ of substrate, $20 \mu \mathrm{L}$ of $11.4 \mathrm{mM} \mathrm{NAD}$ and $2.8 \mathrm{ml}$ of $50 \mathrm{mM}$ of sodium phosphate buffer, $\mathrm{pH}$ 8.5. The mixture also contained $50 \mu \mathrm{l}$ of a $12 \mathrm{mM}$ solution of 4-methylpyrazole as a specific inhibitor of $\mathrm{ADH}$ activity. The fluorescence was read at an excitation wavelength of 310 and an emission wavelength of $360 \mathrm{~nm}$ on a Shimadzu RF5301 spectrofluorophotometer (Shimadzu Europa GmbH, Duisburg, Germany).

Determination of class I and II ADH isoenzymes. Class I and II ADH isoenzyme activity was measured using fluorogenic substrates (4-methoxy-1-naphthaldehyde for class I and 6-methoxy-2naphthaldehyde for class II) in a reduction reaction according to Wierzchowski et al. (11). The assays were performed in a reaction mixture containing a serum $(60 \mu \mathrm{L})$, substrate $(150 \mu \mathrm{L}$ of $300 \mu \mathrm{M})$, $\mathrm{NADH}(100 \mu \mathrm{l}$ of $1 \mathrm{mM})$ and $0,1 \mathrm{M}$ of sodium phosphate buffer, $\mathrm{pH} 7.6(2.69 \mathrm{ml})$ using the conditions previously described (12). The measurements were performed on a Shimadzu RF-5301 spectrofluorophotometer at an excitation wavelength of $316 \mathrm{~nm}$ for both substrates and emission of $370 \mathrm{~nm}$ for class I and $360 \mathrm{~nm}$ for class II isoenzymes.

Determination of class III ADH isoenzyme. The assay mixture for class III alcohol dehydrogenase contained a serum $(100 \mu \mathrm{l})$, formaldehyde as a substrate $(100 \mu \mathrm{l}$ of $1 \mathrm{mM})$, glutathione $(100 \mu \mathrm{l}$ of $1 \mathrm{mM})$ and NAD $(240 \mu \mathrm{l}$ of $1.2 \mathrm{mM})$ in $0.1 \mathrm{~mol} \mathrm{NaOH}-$ pyrophosphate buffer $\mathrm{pH} 8.0$ (13). The final volume was $2 \mathrm{ml}$. The reduction of NAD was monitored at $340 \mathrm{~nm}$ and $25^{\circ} \mathrm{C}$ on a Shimadzu UV/VIS 1202 spectrophotometer.
Determination of class IV ADH isoenzyme. The assay mixture for class IV of ADH activity contained serum $(50 \mu \mathrm{l})$, mnitrobenzaldehyde as a substrate $(132 \mu \mathrm{l}$ of $80 \mu \mathrm{M})$ and NADH (172 $\mu \mathrm{l}$ of $86 \mu \mathrm{M})$ in $0.1 \mathrm{M}$ sodium phosphate buffer $\mathrm{pH} 7.5$ (14). The oxidation of NADH was monitored at $340 \mathrm{~nm}$ and $25^{\circ} \mathrm{C}$ on a Shimadzu UV/VIS 1202 spectrophotometer.

Diagnostic values calculation. The diagnostic criteria, such as the diagnostic sensitivity, diagnostic specificity, predictive value of positive (PPV) and negative (NPV) results and the ROC curve, were determined using GraphRoc Program for Windows (University of Turku, Turku, Finland) (15). For the diagnostic accuracy calculations and the ROC curve we used the total PCa patients group $v s$. control group.

Statistical analysis. Preliminary statistical analysis (Chi-square test) revealed that the distribution of ADH and ALDH activities did not follow a normal distribution. The differences between tested and control groups were evaluated by Mann-Whitney $U$-test. Data were presented as median and the mean values \pm standard deviation. Statistically significant differences were defined as comparisons resulting in $p<0.05$.

\section{Results}

The activities of total ADH, ALDH and ADH isoenzymes in sera of patients with prostate cancer are presented in Table I. We have found that the total alcohol dehydrogenase activity was significantly higher in patients with prostate cancer and in the BPH group compared to healthy subjects. The mean total activity of $\mathrm{ADH}$ was $1.80 \mathrm{IU} / \mathrm{l}$ in sera of cancer patients, $1.82 \mathrm{IU} / 1$ in patients with benign hyperplasia and $0.95 \mathrm{IU} / \mathrm{l}$ in the control group. We also observed that ALDH activity is significantly lower in the PCa group $(1.90 \mathrm{mIU} / \mathrm{l})$ and BPH patients $(1.52 \mathrm{mIU} / \mathrm{l})$ in contrast to controls $(7.23 \mathrm{mIU} / \mathrm{l})$. We did not observe significant differences in ADH and ALDH activity between cancer and $\mathrm{BPH}$ group.

The comparison of ADH isoenzymes showed that both, ADH III and ADH IV activities are significantly higher in the sera of patients with prostate cancer and with benign lesions compared with healthy individuals. The activity of class III ADH was 75.99 $\mathrm{mIU} / \mathrm{l}$ in PCa group, $68.79 \mathrm{mIU} / \mathrm{l}$ in $\mathrm{BPH}$ patients and 8.90 $\mathrm{mIU} / \mathrm{l}$ in controls. The activity of ADH IV was lower than the activity of class III and reached $42.09 \mathrm{mIU} / \mathrm{l}$ in cancer, 54.72 $\mathrm{mIU} / \mathrm{l}$ in BPH and $12.19 \mathrm{mIU} / 1$ in control group. Class III and IV of ADH did not indicate significant differences between BPH and control group. We have also observed that the activity of ADH I was significantly lower in the sera of patients with prostate cancer $(0.94 \mathrm{mIU} / \mathrm{l})$ and in BPH group $(1.15 \mathrm{mIU} / \mathrm{l})$ compared to controls $(1.89 \mathrm{mIU} / \mathrm{l})$. In contrast, the activity of class II ADH was also significantly lower only in prostate cancer patients in contrast to BPH and healthy individuals. The mean activity of this class ADH was $6.98 \mathrm{mIU} / 1$ in sera of cancer patients, $13.44 \mathrm{mIU} / 1$ in patients with benign hyperplasia and $14.01 \mathrm{mIU} / \mathrm{l}$ in the control group. We did not observe significant differences in ADH II activity between BPH and control group. 
Table I. The comparison of ADH isoenzymes and ALDH activities in the sera of prostate cancer patients.

\begin{tabular}{|c|c|c|c|c|c|c|}
\hline $\begin{array}{l}\text { Tested } \\
\text { group }\end{array}$ & $\begin{array}{c}\text { ADH I } \\
\text { Mean } \pm \text { SD } \\
\text { Median }\end{array}$ & $\begin{array}{c}\text { ADH II } \\
\text { Mean } \pm \text { SD } \\
\text { Median }\end{array}$ & $\begin{array}{l}\text { ADH III } \\
\text { Mean } \pm \text { SD } \\
\text { Median }\end{array}$ & $\begin{array}{l}\text { ADH IV } \\
\text { Mean } \pm \text { SD } \\
\text { Median }\end{array}$ & $\begin{array}{c}\text { ADH Total } \\
\text { Mean } \pm \text { SD } \\
\text { Median }\end{array}$ & $\begin{array}{c}\text { ALDH Total } \\
\text { Mean } \pm \text { SD } \\
\text { Median }\end{array}$ \\
\hline $\begin{array}{l}\text { Prostate cancer } \\
(\mathrm{n}=52)\end{array}$ & $\begin{array}{c}0.94 \pm 0.85 \\
0.66\end{array}$ & $\begin{array}{c}6.98 \pm 5.09 \\
6.11\end{array}$ & $\begin{array}{c}75.99 \pm 46.96 \\
60.00\end{array}$ & $\begin{array}{c}42.09 \pm 35.00 \\
30.23\end{array}$ & $\begin{array}{c}1.80 \pm 1.78 \\
1.17\end{array}$ & $\begin{array}{c}1.90 \pm 2.74 \\
1.03\end{array}$ \\
\hline $\begin{array}{l}\mathrm{BPH} \\
(\mathrm{n}=34)\end{array}$ & $\begin{array}{c}1.15 \pm 0.84 \\
0.97\end{array}$ & $\begin{array}{c}13.44 \pm 7.41 \\
15.35\end{array}$ & $\begin{array}{c}68.79 \pm 43.44 \\
61.41\end{array}$ & $\begin{array}{c}54.72 \pm 78.98 \\
18.01\end{array}$ & $\begin{array}{c}1.82 \pm 1.18 \\
1.94\end{array}$ & $\begin{array}{c}1.52 \pm 0.95 \\
1.55\end{array}$ \\
\hline $\begin{array}{l}\text { Control group } \\
(n=60)\end{array}$ & $\begin{array}{c}1.89 \pm 0.92 \\
1.88 \\
\\
p^{\mathrm{a}}<0.001 \\
p^{\mathrm{b}}=0.113 \\
p^{\mathrm{c}}<0.001\end{array}$ & $\begin{array}{c}14.01 \pm 3.37 \\
14.26 \\
p^{\mathrm{a}}<0.001 \\
p^{\mathrm{b}}<0.001 \\
p^{\mathrm{c}}=0.786\end{array}$ & $\begin{array}{c}8.90 \pm 2.53 \\
8.56 \\
p^{\mathrm{a}}<0.001 \\
p^{\mathrm{b}}=0.527 \\
p^{\mathrm{c}}<0.001\end{array}$ & $\begin{array}{c}12.19 \pm 3.87 \\
12.47 \\
p^{\mathrm{a}}<0.001 \\
p^{\mathrm{b}}=0.137 \\
p^{\mathrm{c}}<0.001\end{array}$ & $\begin{array}{c}0.95 \pm 0.48 \\
0.84 \\
p^{\mathrm{a}=}=0.047 \\
p^{\mathrm{b}}=0.539 \\
p^{\mathrm{c}}<0.001\end{array}$ & $\begin{array}{c}7.23 \pm 2.45 \\
7.31 \\
p^{\mathrm{a}}<0.001 \\
p^{\mathrm{b}}=0.325 \\
p^{\mathrm{c}}<0.001\end{array}$ \\
\hline
\end{tabular}

SD: Standard deviation; BPH: benign prostate hyperplasia. Statistically significant differences were defined as comparisons resulting in $p<0.05$. Data are expressed as mIUl/l (ADH total- IU/l). $p^{\mathrm{a}}$, cancer patients $v s$. controls; $p^{\mathrm{b}}$, cancer patients $v s$. BPH patients; $p^{\mathrm{c}}$, BPH patients $v s$. controls.

Table II. Diagnostic criteria for ADH total and ADH isoenzymes for prostate cancer.

\begin{tabular}{lcccccc}
\hline & $\begin{array}{c}\text { Cut-off } \\
(\mathrm{mIU} / \mathrm{l})\end{array}$ & $\begin{array}{c}\text { Diagnostic } \\
\text { sensitivity }(\%)\end{array}$ & $\begin{array}{c}\text { Diagnostic } \\
\text { specificity }(\%)\end{array}$ & $\begin{array}{c}\text { Positive predictive } \\
\text { value }(\%)\end{array}$ & $\begin{array}{c}\text { Negative predictive } \\
\text { value }(\%)\end{array}$ & $\begin{array}{c}\text { Accuracy } \\
(\%)\end{array}$ \\
\hline ADH III & 17.36 & 94.2 & 100 & 100 & 95.2 & 97.3 \\
ADH IV & 14.79 & 90.4 & 76.7 & 77.0 & 90.2 & 83.0 \\
ADH total & 2.21 & 32.7 & 61.0 & 62.0 & 63.2 \\
\hline
\end{tabular}

Table II shows the diagnostic criteria for ADH III, ADH IV and ADH total. The sensitivity (94.2\%) and specificity $(100 \%)$ of class III ADH were higher than that for isoenzyme class IV ( $90.4 \%$ and $76.7 \%$ respectively). Both positive and negative predictive values were also the highest for the activity of ADH III (100\% and 95.2\%). The accuracy was $97.3 \%$ for the ADH III activity and only $83 \%$ for ADH IV. All diagnostic criteria for the total activity of ADH were much lower than that for isoenzymes class III and IV.

The relationship between diagnostic sensitivity and specificity was illustrated by a ROC curve (Figure 1). It shows that areas under the ROC curve for ADH III (0.993) and for ADH IV (0.904) activity were much higher than the ROC area of the total ADH (0.609).

\section{Discussion}

The role of alcohol consumption on prostate cancer remains uncertain. There have been conflicting reports of possible associations of ethanol use with $\mathrm{PCa}$, emphasizing on the need for research in this field. There are a number of biological mechanisms that may explain the link between alcohol consumption and cancer development. One theory concerns high acetaldehyde exposure, causes mutations and sister chromatid exchanges in human cells. Moreover, acetaldehyde interferes at many sites with DNA synthesis and repair, and by binding to DNA and cellular protein, forms adducts that result in cancer development (16). Chronic ethanol consumption generates production of reactive oxygen species (ROS), that result in oxidative damage of proteins, lipids and nucleic acids (17). Furthermore, alcohol causes disturbances in retinoic acid biosynthesis, leading to an increased risk for cell proliferation and malignant transformation (18).

Data have shown that cancer cells have the ability to release alcohol dehydrogenase (ADH) isoenzymes to the blood of patients (8). This suggests that increased ADH activity in the sera of prostate cancer patients may be due to enzyme released from cancer cells. We have shown a significant increase in total alcohol dehydrogenase activity and a significant decrease in aldehyde dehydrogenase in the sera of patients with prostate cancer. These changes in enzymes activity provide evidence that there is a tendency to higher acetaldehyde production and lower 


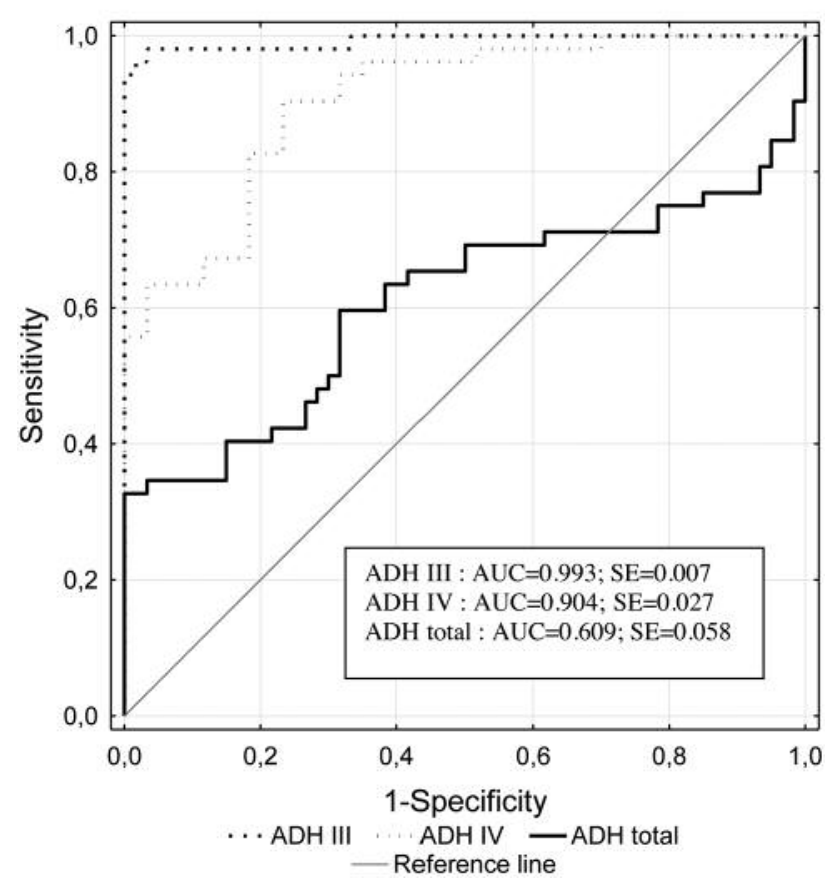

Figure 1. Receiver-operating characteristic (ROC) curves for alcohol dehydrogenase class III (ADH III), class IV (ADH IV) and total alcohol dehydrogenase (ADH total) activity. AUC: Area under curve; SE: standard error of the mean.

ability to remove this carcinogenic compound. The significantly elevated ADH activity was found in the sera of patients with malignant diseases of the esophagus, stomach, liver, pancreas, colorectum, kidney, urinary bladder, endometrium, cervix or brain (8).

The increase of ADH activity in prostate patients is a result of significantly elevated activity of isoenzymes class III and IV ADH. Class IV reveals the main role of ethanol oxidation so increased activity of this class causes elevated production of acetaldehyde. Moreover, this class of ADH takes part in the metabolism of lipid peroxidation products, that may also intensify prostate carcinogenesis. The end products of lipid peroxidation may damage DNA through formation of exocyclic adducts. The main products of lipid peroxidation are: crotonaldehyde, acrolein, 4-hydroxy-2-nonenal and malondialdehyde (19). Moreover, the activity of ADH IV in retinol metabolism is 6 times higher than for ADH II and 14 times higher than for ADH class I so in the case of lower ALDH activity retinoic acid biosynthesis pathway is also disturbed (20). ADH III participates mainly in metabolism of endogenous long-chain alcohols and aldehydes. This class of ADH catalyzes the oxidation of S-hydroxymethylglutathione and disturbances in its activity may lead to depletion of glutathione, which is a strong antioxidant compound that is important for the maintenance of redox state in cells. The consequence of decreased glutathione concentration may be generation of reactive oxygen species and induction of oxidative stress leading to cancer development (21).

Molecules associated with prostate cancer may serve as a basis for designing non-invasive diagnostic tests. The ideal cancer marker should be characterized by high specificity, high sensitivity and suitable value of area under ROC curve. PSA has been widely used, is the preferred assay for prostate cancer diagnosis and represents the gold standard marker for urologists worldwide. However, this test is not prostate cancer specific but could also be elevated in benign prostate hyperplasia, prostatitis and in prostate manipulations. The literature data show that diagnostic significance of the prostate cancer biomarkers is the subject of many researches. The Prostate Health Index (PHI) is a mathematical formula which relies on the different proportions of specific biomarkers (tPSA, fPSA, -2proPSA). PHI provides additional information in differentiation of benign prostatic conditions and PCa. PHI was found to have greater AUC (0.73) than PSA alone (0.382) (22). In our study, we defined that the area under ROC curve for $\mathrm{ADH}$ III and ADH IV was higher in prostate cancer than for PHI (0.993 and 0.904 respectively). The 4Kscore test is determined on serum levels of 4 human kalikreins (tPSA, fPSA, intact PSA, human kalikrein 2) in combination with clinical information. The AUC value of $4 \mathrm{Kscores}$ is higher than for PSA alone and PHI but lower than for ADH isoenzymes (0.821) (23). Urinary biomarker - PCa antigen 3 (PCA3) has been shown to have a variable sensitivity, specificity, PPV and NPV. PCA3 sensitivity was 58-82\%, specificity 58-76\%, PPV and NPV $67 \%$ and $87 \%$ respectively $(24,25)$. All diagnostic criteria for ADH class III and IV was higher than for PCA3. AUC value for PCA3 in prostate cancer was $0.68-0.87$ and was also lower than for ADH isoenzymes. \% $\alpha 2,3$-sialic acid test identifies PSA glycoforms containing $\alpha 2,3$-sialic acid, which have been linked to PCa aggressiveness. Data have shown that combination of both markers, \% $\% 2,3$-sialic acid and PHI gave better values of diagnostic criteria (sensitivity $100 \%$, specificity 94\%, AUC 0.985), similar to ADH class III and IV (26).

This is the first study showing all the diagnostic criteria for alcohol dehydrogenase and aldehyde dehydrogenase in prostate cancer. These results highlight that the future of prostate cancer diagnosis might relay on the combination of a panel of markers where alcohol dehydrogenase isoenzymes activity might also be included.

\section{References}

1 Siegel RL, Miller KD and Jemal A: Cancer statistics, 2015. CA Cancer J Clin 65: 5-29, 2015.

2 Kalantari E, Saadi FH, Asgari M, Shariftabrizi A, Roudi R and Madjd Z: Increased expression of ALDH1A1 in prostate cancer is correlated with tumor aggressiveness: a tissue microarray study of iranian patients. Appl Immunohistochem Mol Morphol, 2016. 
3 McGrath S, Christidis D, Perera M, Hong SK, Manning T, Vela I and Lawrentschuk N: Prostate cancer biomarkers: Are we hitting the mark? Prostate Int 4: 130-135, 2016.

4 Boffetta P, Hashibe M, La Vecchia C, Zatonski W and Rehm J: The burden of cancer attributable to alcohol drinking. Int $\mathrm{J}$ Cancer 119: 884-887, 2006.

5 Tonnesen H, Moller H, Andersen JR, Jensen E and Juel K: Cancer morbidity in alcohol abusers. Br J Cancer 69: 327-332, 1994.

6 Dennis LK: Meta-analysis for combining relative risk of alcohol consumption and prostate cancer. Prostate 42: 56-66, 2000.

7 Hayes RB, Brown LM, Schoenberg JB, Greenberg RS, Silverman DT, Schwartz AG, Swanson GM, Benichou J, Liff JM, Hoover RN and Pottern LM: Alcohol use and prostate cancer risk in US blacks and whites. Am J Epidemiol 143: 692697, 1996

8 Orywal K and Szmitkowski M: Alcohol dehydrogenase and aldehyde dehydrogenase in malignant neoplasms. Clin Exp Med 17: 131-139, 2017.

9 Skursky L, Kovar J and Stachova MA: Sensitive assay for alcohol dehydrogenase activity in blood serum. Anal Biochem 89: 65-71, 1979.

10 Wierzchowski J, Wroczyński P, Laszuk K and Interewicz E: Fluorimetric detection of aldehyde dehydrogenase activity in human blood, saliva, and organ biopsies and kinetic differentiation between class I and II isozymes. Anal Biochem 245: 69-78, 1997.

11 Wierzchowski J, Dafeldecker W, Holmquist B and Vallee BL: Fluorimetric assay for isozymes of human alcohol dehydrogenase. Anal Biochem 178: 57-62, 1989.

12 Jelski W, Chrostek L, Szmitkowski M and Laszewicz W: The activity of class I, II, III and IV of alcohol dehydrogenase isoenzymes in human gastric mucosa. Dig Dis Sci 47: 15541557, 2002.

13 Koivusalo M, Baumann M and Uotila L: Evidence for the identity of glutathione-dependent formaldehyde dehydrogenase and class III alcohol dehydrogenase. FEBS Lett 257: 105-109, 1989.

14 Dohmen K, Baraona E, Ishibashi H, Pozzato G, Moretti M, Matsunaga C, Fujimoto K and Lieber CS: Ethnic differences in gastric $\sigma$-alcohol dehydrogenase activity and ethanol first metabolism. Alcohol Clin Exp Res 20: 1569-1576, 1996.

15 Kairisto V, Virtanen A, Uusipaikka E, Voipio-Pulkki LM, Näntö $\mathrm{V}$, Peltola $\mathrm{O}$ and Iriala $\mathrm{K}$ : Method for determining reference changes from patients' several data: Example of cardiac enzymes. Clin Chem 39: 2298-2304, 1993.

16 Seitz HK and Meier P: The role of acetaldehyde in upper digestive tract cancer in alcoholics. Trans Res 149: 293-297, 2007.

17 Seitz HK and Sticker F: Risk factors and mechanisms of hepatocarcinogenesis with special emphases of on alcohol and oxidative stress. Biol Chem 387: 349-360, 2006.
18 Seitz HK: Alcohol and retinoid metabolism. Gut 47: 748-750, 2000.

19 De Bont R and van Larebeke N: Endogenous DNA damage in humans: a review of quantitative data. Mutagenesis 19: 169-185, 2004.

20 Yin SJ, Chou CF, Lai CI, Lee SL and Han CL: Human class IV alcohol dehydrogenase: kinetic mechanism, functional roles and medical relevance. Chem-Biolog Interact 143: 219-227, 2003.

21 Jelski W, Chrostek L and Szmitkowski M: The activity of class I, II, III and IV of alcohol dehydrogenase isoenzymes and aldehyde dehydrogenase in pancreatic cancer. Pancreas 35: 142146, 2007.

22 Catalona WJ, Partin AW, Sanda MG, Wei JT, Klee GG, Bangma CH, Slawin KM, Marks LS, Loeb S, Broyles DL, Shin SS, Cruz AB, Chan DW, Sokoll LJ, Roberts WL, van Schaik RH and Mizrahi IA: A multicenter study of (-2)pro-prostate specific antigen combined with prostate specific antigen and free prostate specific antigen for prostate cancer detection in the 2.0 to 10.0 ng/ml prostate specific antigen range. J Urol 185: 1650-5, 2011.

23 Parekh DJ, Punnen S, Sjoberg DD, Asroff SW, Bailen JL, Cochran JS, Concepcion R, David RD, Deck KB, Dumbadze I, Gambla M, Grable MS, Henderson RJ, Karsh L, Krisch EB, Langford TD, Lin DW, McGee SM, Munoz JJ, Pieczonka CM, Rieger-Christ K, Saltzstein DR, Scott JW, Shore ND, Sieber PR, Waldmann TM, Wolk FN and Zappala SM: A multiinstutional prospective trial in the USA confirms that the 4Kscore accurately identifies men with high-grade prostate cancer. Eur Urol 68: 464-470, 2015.

24 Marks LS and Bostwick DG: PCA3 molecular urine assay for prostate cancer in men undergoing repeat biopsy. Urology 69: 532-535, 2007.

25 Leyten GH, Hessels D, Jannink SA, Smit FP, de Jong H, Cornel EB, de Reijke TM, Vergunst H, Kil P, Knipscheer BC, van Oort IM, Mulders PF, Hulsbergen-van de Kaa CA and Schalken JA: Prospective multicenter evaluation of PCA3 and TMPRSS2ERG gene fusions as diagnostic and prognostic urinary biomarkers for prostate cancer. Eur Urol 65: 534-542, 2014.

26 Ferrer-Batallé M, Llop E, Ramírez M, Aleixandre RN, Saez M, Comet J, de Llorens R and Peracaula R: Comparative study of blood-based biomarkers, $\alpha 2,3$-sialic acid PSA and PHI, for highrisk prostate cancer detection. Int J Mol Sci 18: E845, 2017.
Received July 4, 2017

Revised July 25, 2017

Accepted July 26, 2017 